\title{
Kandungan flavanoid total dan aktivitas antimikroba serbuk biji kakao (Theobroma cacao) asal Kabupaten Enrekang Sulawesi Selatan
}

\author{
Andi Emelda, Rusli, Irma Santi \\ Fakultas Farmasi, Universitas Muslim Indonesia, \\ Jl. Perintis Kemerdekaan KM.5 Makassar 90231, South Sulawesi Indonesia \\ Submitted: 05-06-2016 \\ Reviewed: 02-11-2016 \\ Accepted: 03-11-2016
}

\begin{abstract}
ABSTRAK
Kakao dan derivatnya kaya akan flavanoid. Kandungan flavanoid dari biji kakao dipengaruhi oleh proses pengolahannya. Tujuan dari penelitian ini untuk menentukan total flavanoid dan aktivitas antimikroba dari serbuk biji kakao. Penelitian ini menggunakan biji kakao dalam kondisi unfermented. Biji kakao dibuat dalam bentuk serbuk. Pengujian total flavanoid dilakukan dengan metode aluminium chloride colorimetric assay. Pengujian konsentrasi Hambat Minimum (KHM), Konsentrasi Bunuh Minimum (KBM) dan aktivitas antimikroba serbuk biji kakao dengan menggunakan beberapa bakteri uji yaitu Staphylococcus Epidermidis, Bacillus subtilis, Escherichia coli, Salmonella thypi, Shigella dysentriae, Pseudomonas aeruginosa, Staphylococcus aureus, Streptococcus mutans, Vibrio cholera, Propioni bacterium agne. Hasil pengukuran kadar total flavanoid serbuk biji kakao adalah sebesar 22,62 mg EK/g. Pada skrining antimikroba konsentrasi 0,1\% serbuk biji kakao memberikan penghambatan pada Streptococcus mutans, Shigella dysentriae, Escherichia coli, Vibrio cholera dan Propioni bacterium agne. Konsentrasi $0,5 \%$ memberikan penghambatan pada semua bakteri uji. Aktivitas antimikroba menggunakan konsentrasi $0,5 \%, 1 \%, 2 \%$ dan $4 \%$. Zona hambatan terbesar ditunjukkan pada konsentrasi 4\%. Diameter zona hambat untuk bakteri Shigella dysentriae adalah $11,33 \mathrm{~mm}$. Diameter zona hambat $10 \mathrm{~mm}$ ditunjukkan oleh bakteri Streptococcus mutans, Escherichia coli, Propioni bacterium agne, Staphylococcus aureus dan Bacillus subtilis. Zona hambat $11 \mathrm{~mm}$ ditunjukkan oleh Salmonella thypi dan Staphylococcus Epidermidis, sedangkan Pseudomonas aeruginosa menunjukkan zona hambatan $12 \mathrm{~mm}$. Biji kakao yang dibuat dalam kondisi unfermented memberikan total Flavanoid 22,62 mg EK/g dan mempunyai efek antimikroba.
\end{abstract}

Kata Kunci: serbuk, biji kakao, aktivitas antimikroba, flavanoid

\begin{abstract}
Cocoa and its derivatives are rich in flavonoids. Flavonoid content of cocoa beans is affected by the treatment process. The aim of this study are to determine total flavonoids and antimicrobial activity of cocoa powder. This study used unfermented cocoa beans in the form of powder. Testing of the total flavonoids was conducted using an aluminum chloride colorimetric assay. The minimum inhibitory concentration (MIC), Minimum Bactericidal Concentration (MBC), and antimicrobial activity of cocoa bean powder were tested by using ten bacteria: Staphylococcus epidermidis, Bacillus subtilis, Escherichia coli, Salmonella thypi, Shigella dysentriae, Pseudomonas aeruginosa, Staphylococcus aureus, Streptococcus mutans, Vibrio cholerae, and Propioni bacterium agne. The result of measurement of the total flavonoid of unfermented cocoa powder is $22.62 \mathrm{mg} \mathrm{EC} / \mathrm{g}$. The screening of antimicrobial with concentration of $0.1 \%$ of cocoa powder gives inhibition in Streptococcus mutans, dysentriae Shigella, Escherichia coli, Vibrio cholerae bacterium and Propioni bacterium agne, while at a concentration of $0.5 \%$ gives inhibition at all test bacteria.
\end{abstract}

Penulis korespondesi:

Andi Emelda

Fakultas Farmasi, Universitas Muslim Indonesia,

J1. Perintis Kemerdekaan KM.5 Makassar 90231, South Sulawesi Indonesia

Email: andi.emelda@umi.ac.id 
In the antimicrobial activity test using a concentration of $0.5 \%, 1 \%, 2 \%$ and $4 \%$, the highest resistance zone is shown at a concentration of $4 \%$. The results show that the diameter zone of inhibition for the bacteria Shigella dysentriae is $11.33 \mathrm{~mm}$. The $10 \mathrm{~mm}$ of diameter zone of inhibition are indicated by streptococcus mutans, Escherichia coli, Propioni bacterium agne, Staphylococcus aureus and Bacillus subtilis while $11 \mathrm{~mm}$ zone of inhibition demonstrated by Salmonella thypi and Staphylococcus epidermidis. The number of the diameter zone of inhibition, $12 \mathrm{~mm}$, was shown in Pseudomonas aeruginosa. In conclusion, the powder of unfermented cocoa beans provides flavonoids 22,62 $\mathrm{mg}$ EK/g and have the antimicrobial activity.

Keywords: cocoa bean, powder, antimicrobial activity, flavonoid

\section{PENDAHULUAN}

Biji kakao memiliki kandungan flavonoid yang tinggi dibandingkan dengan beberapa sayuran dan buah. Flavanoid secara luas didistribusikan didalam tumbuhan dan merupakan metabolit sekunder. Lebih dari 8.000 struktur fenolik saat ini sudah dikenal, mulai dari molekul yang sederhana seperti asam fenolik dan zat terpolimerisasi seperti tanin (Dai dan Mumper, 2010; Cheynier, 2012 ). Kandungan flavanoid pada tanaman dapat berperan sebagai antibakteri seperti pada penelitian pada daun binahong (CassiaAlata L). Mekanisme kerja zat-zat dalam menghambat pertumbuhan bakteri, antara lain menyebabkan terjadinya kerusakan permeabilitas dinding sel bakteri (Kurniawan B, Aryana w,F,2015).

Biji kakao mentah adalah salah satu makanan yang paling bergizi di dunia, dan melindungi tubuh dari dampak radikal bebas, mengurangi stres dan depresi, melindungi terhadap penyakit jantung dan pembuluh darah, melindungi terhadap berbagai jenis kanker, mengatur gula darah dan kadar kolesterol, memberikan peningkatkan memori yang lebih baik, mengurangi risiko serangan jantung dan membantu mengatur tekanan darah (Latif, 2013). Biji kakao diselimuti dengan cairan yang memiliki rasa manis asam dan kaya gula dan senyawa bioaktif. Cairan ini merupakan sumber untuk pengembangan mikroorganisme yang bertanggung jawab untuk fermentasi dan penting dalam pembentukan aroma dan rasa dari produk akhirnya (Ouattara et al., 2014 ).

Biji kakao memiliki aktivitas antioksidan yang dihubungankan dengan kandungan senyawa fenolik dalam produk (Miller et al., 2009; Lucena, 2010). Pengukuran flavanoid total ekstrak terpurifikasi biji kakao yang unfermented asal Sulawesi Barat menggunakan metode aluminium chloride colorimetric assay diperoleh 272,2 mg/g dihitung sebagai katekin dengan kandungan kafein dan theobromin yang sangat kecil (Emelda dan Wahyudin, 2014). Biji kakao mengandung methylxanthines yang bisa mengurangi kapasitas antioksidan flavonoid dalam coklat bubuk (Maleyki dan Ismail, 2010). Pengukuran polifenol total serbuk dan ekstrak terpurifikasi biji kakao dari Kabupaten Enrekang Sulawesi Selatan diperoleh berturut-turut $151 \mathrm{mg}$ EAT/g dan 373,57 mg EAT/g (Emelda et al., 2015). Pada penelitian ini bertujuan untuk menentukan flavanoid total dan aktivitas antimikroba dari biji kakao unfermented asal kabupaten Enrekang.

\section{METODE PENELITIAN}

\section{Alat dan Bahan}

Seperangkat Alat maserasi, penangas air, timbangan analitik, labu ekstraksi, cawan petri, rotary evaporator, inkubator, laminair air flow, autoklaf, mikropipet. Biji kakao (Theobroma cacao), bakteri uji Shigella dysentriae, Staphylococcus Epidermidis, Bacillus subtilis, Escherichia coli, Salmonella thyp, Pseudomonas aeruginosa, Staphylococcus aureus, Streptococcus mutans, Vibrio cholera, Propioni bacterium agne. yang diperoleh dari Laboratorium Mikrobiologi Program Studi Farmasi Fakultas Farmasi Universitas Muslim Indonsia.

\section{Jalannya Penelitian \\ Penyiapan bahan}

Buah kakao yang di peroleh dikeluarkan bijinya dan dibersihkan dari lendir yang terdapat pada buah. Kemudian dikeringkan pada suhu $40^{\circ} \mathrm{C}$. Biji kakao yang telah kering dikupas kulit bijinya lalu diserbukan dan siap digunakan sebagai bahan penelitian.

\section{Penentuan total flavanoid}

Kandungan flavanoid serbuk biji kakao (Thebroma cacao) ditentukan dengan metode aluminium chloride colorimetric assay (Marinova et al., 2005). serbuk sebanyak 251,13 mg dilarutkan dengan 
pelarut metanol. Volume dicukupkan hingga $50 \mathrm{ml}$ dalam labu takar. $1 \mathrm{~mL}$ dipipet dan dimasukkan dalam labu takar $50 \mathrm{ml}$ lalu ditambahkan $20 \mathrm{ml}$ air suling. Sebanyak 1,5 $\mathrm{mL} \mathrm{N}_{\mathrm{a}} \mathrm{NO}_{2} 5 \%$ dibiarkan selama 5 menit. Setelah 5 menit ditambahkan $0,15 \mathrm{~mL} \mathrm{AlCl}_{3}$ 10\%. Ditambahkan $10 \mathrm{~mL} \mathrm{NaOH} 1 \mathrm{M}$ dan dicukupkan $50 \mathrm{~mL}$ dengan air suling. Larutan diukur absorbannya pada $510 \mathrm{~nm}$. Kurva standar dibuat menggunakan berbagai konsentrasi katekin. Hasilnya dinyatakan sebagai persen katekin.

\section{Uji skrining antibakteri}

Serbuk dari biji kakao $10 \mathrm{mg}$ ditimbang untuk membuat 0,1\%, dilarutkan dengan DMSO 0,2 mL. Wadah yang telah berisi campuran serbuk dan DMSO dituang ke dalam cawan petri dan ditambahkan medium NA sebanyak $9,8 \mathrm{~mL}$, dihomogenkan dan dibiarkan memadat. Suspensi bakteri digoreskan pada medium NA yang telah memadat kemudian diinkubasi pada suhu $37^{\circ} \mathrm{C}$ selama 1 x 24 jam. Diamati aktivitas antibakterinya yang ditandai dengan ada atau tidaknya pertumbuhan bakteri (Efendi, Y.N and Hertiani,T., 2013).

\section{Pengujian Konsentrasi Hambat Minimum (KHM)}

Sampel dibuat dengan konsentrasi $0,1 \%, 0,2 \%, 0,4 \%, 0,8 \%, 1,6 \%$. Masing-masing konsentrasi dimasukan ke dalam tabung reaksi steril, di tambahkan medium Nutrien Broth (NB). Setelah itu masingmasing tabung reaksi dimasukkan suspensi bakteri uji. Diinkubasi pada suhu $37^{\circ} \mathrm{C}$ selama 24 jam. Konsentrasi terendah yang menunjukkan larutan tetap jernih menunjukkan harga KHM (Miranti, M., et $a l, 2013)$.

\section{Uji Konsentrasi Bunuh Minimum (KBM)}

Hasil inkubasi pada uji KHM kemudian digoreskan pada medium Nutrien Agar (NA) pada cawan petri, lalu diinkubasi pada suhu $37^{\circ} \mathrm{C}$ selama 24 jam. Nilai KBM ditunjukkan pada konsentrasi terendah dimana tidak terdapat pertumbuhan bakteri (Efendi, Y.N and Hertiani,T., 2013).

\section{Uji aktivitas antibakteri}

Medium Nutrien Agar (NA) steril yang telah dipanaskan dan disterilkan kemudian didinginkan hingga $40-50^{\circ} \mathrm{C}$ lalu dituang secara aseptis ke dalam cawan petri steril sebanyak $10 \mathrm{~mL}$, ditambahkan 20 ul suspensi bakteri uji dan dibiarkan memadat. Disk blank yang sebelumnya telah direndam dengan serbuk biji kakao dengan variasi konsentrasi $0,5 \%, 1 \%, 2 \%$ dan $4 \%$ selama \pm 60 menit, dimasukan ke dalam medium yang telah memadat. Diinkubasi pada suhu $37^{\circ} \mathrm{C}$ selama 24 jam dalam inkubator (Efendi, Y.N and Hertiani,T., 2013).

\section{HASIL DAN PEMBAHASAN}

Biji kakao yang digunakan dalam penelitian ini dibuat dalam kondisi unfermented. Kondisi fermentasi dan unfermented dari biji kakao mempengaruhi senyawa yang terkandung dalam biji kakao tersebut. Biji kakao yang digunakan dalam penelitian ini diperoleh dari kabupaten Enrekang Sulawesi Selatan.

Pada pengukuran kadar Flavanoid menggunakan larutan standar katekin (Sigma), dibuat larutan seri kadar standar katekin yaitu 5, 10,15 dan 20 ppm dan diukur absorbannya pada panjang gelombang $510 \mathrm{~nm}$. Hasil plot absorban standar baku katekin vs konsentrasi dapat dilihat pada Tabel I dan Gambar 1. Penentuan total flavanoid serbuk biji kakao diperoleh 22,62 mg EK/g, pada panjang gelombang $510 \mathrm{~nm}$ dengan nilai absorban 0,137 .

Tabel I. Hasil pengukuran absorban standar baku katekin

\begin{tabular}{cccc}
\hline No & Larutan baku & Konsentrasi (ppm) & Absorban \\
\hline 1. & Standar 1 & 0 & 0,007 \\
2. & Standar 2 & 5 & 0,275 \\
3. & Standar 3 & 10 & 0,486 \\
4. & Standar 4 & 15 & 0,692 \\
5. & Standar 5 & 20 & 0,853 \\
\hline
\end{tabular}




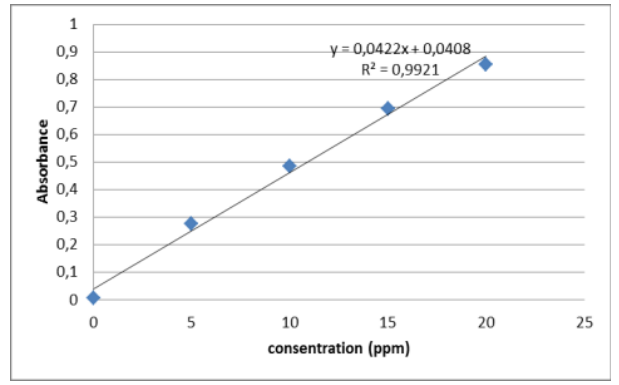

\section{Gambar 1. Kurva standar baku katekin}

Pengujian skrining antimikroba menggunakan bakteri uji yaitu Shigella dysentriae, Staphylococcus Epidermidis, Bacillus subtilis, Escherichia coli, Salmonella thypi, Pseudomonas aeruginosa, Staphylococcus aureus, Streptococcus mutans, Vibrio cholera, Propioni bacterium agne.

Hasil skrining antimikroba ekstrak terpurifikasi dan serbuk biji kakao dapat dilihat pada Tabel II dan Gambar 2.

Tabel II. Skrining antimikroba

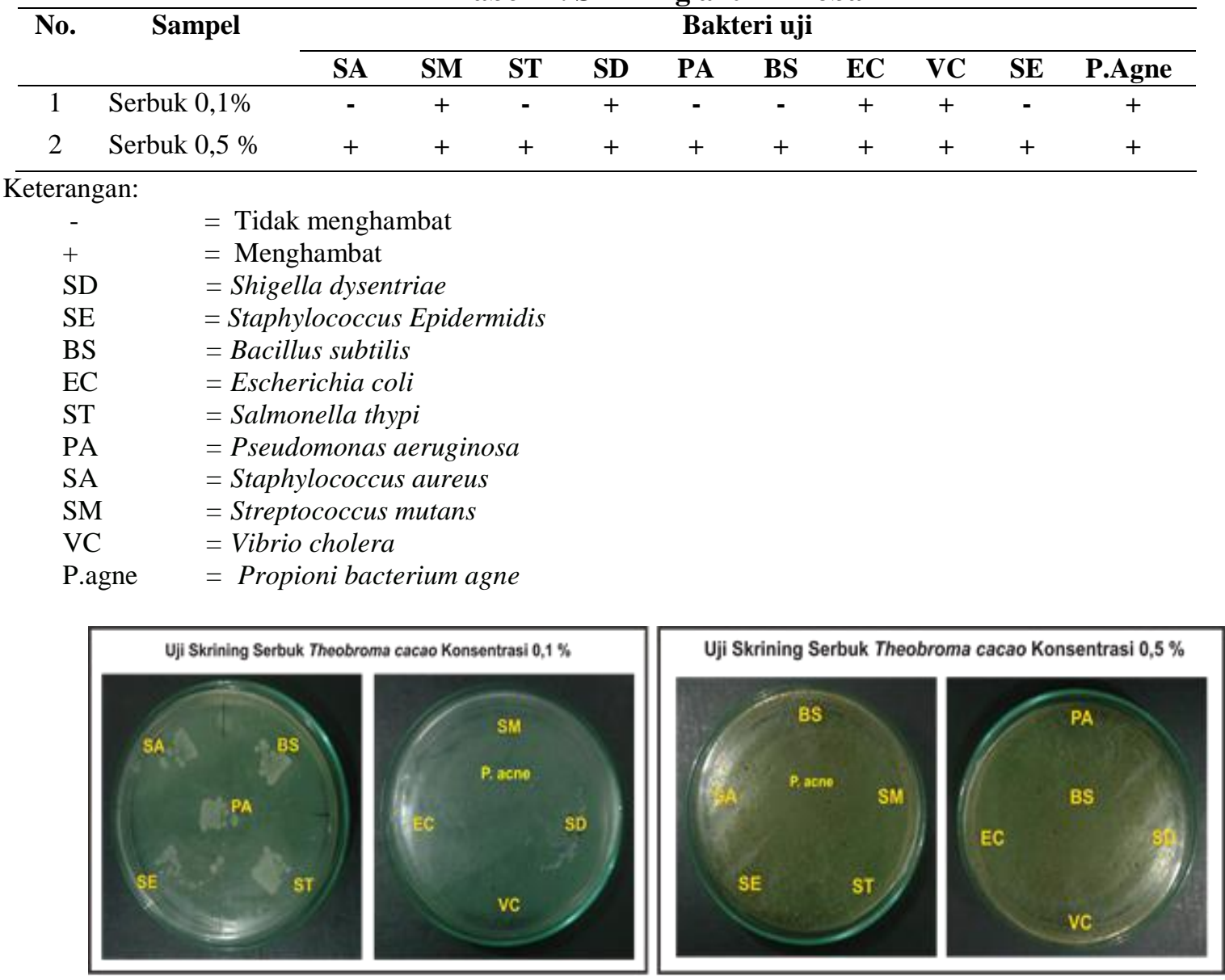

Gambar 2. Hasil skrining antimikroba serbuk biji kakao konsentrasi 0,1\% dan 0,5\%

Tabel II dan Gambar 2 menunjukkan serbuk biji kakao pada konsentrasi 0,1\% hanya dapat menghambat bakteri uji Escherichia coli, Streptococcus mutans, Vibrio cholera, Propioni bacterium agne dan Shigella dysentriae, sedangkan konsentrasi 0,5\% serbuk biji kakao dapat menghambat bakteri uji yaitu Staphylococcus Epidermidis, Bacillus subtilis, Salmonella thypi, Pseudomonas aeruginosa, Staphylococcus aureus, yang tidak dapat dihambat oleh serbuk biji kakao pada konsentrasi $0,1 \%$. Kemampuan ini diduga karena kandungan senyawa konsentrasi $0,5 \%$ lebih banyak dibandingkan $0,1 \%$ sehingga mampu menghambat lebih banyak bakteri uji. 


\section{Pengujian konsentrasi hambat minimum}

Tabel III. Hasil pengujian KHM serbuk 0,1\%

\begin{tabular}{llccccc}
\hline & \multirow{2}{*}{ No. } & Bakteri Uji & \multicolumn{4}{c}{$\begin{array}{c}\text { Konsentrasi Hambat Minimum (KHM) } \\
\text { Serbuk biji kakao (Theobroma cacao) }\end{array}$} \\
\cline { 3 - 6 } & & $\mathbf{0 , 1 \%}$ & $\mathbf{0 , 2 \%}$ & $\mathbf{0 , 4 \%}$ & $\mathbf{0 , 8 \%}$ & $\mathbf{1 , 6 \%}$ \\
\hline 1. & Streptococcus mutans & + & + & + & + & + \\
2. & Shigella dysentriae & + & + & + & + & + \\
3. & Escherichia coli & - & + & + & + & + \\
4. & Vibrio cholera & + & + & + & + & + \\
5. & P.Agne & + & + & + & + & + \\
\hline
\end{tabular}

Keterangan :

- $\quad=$ Tidak menghambat

$+\quad=$ Menghambat
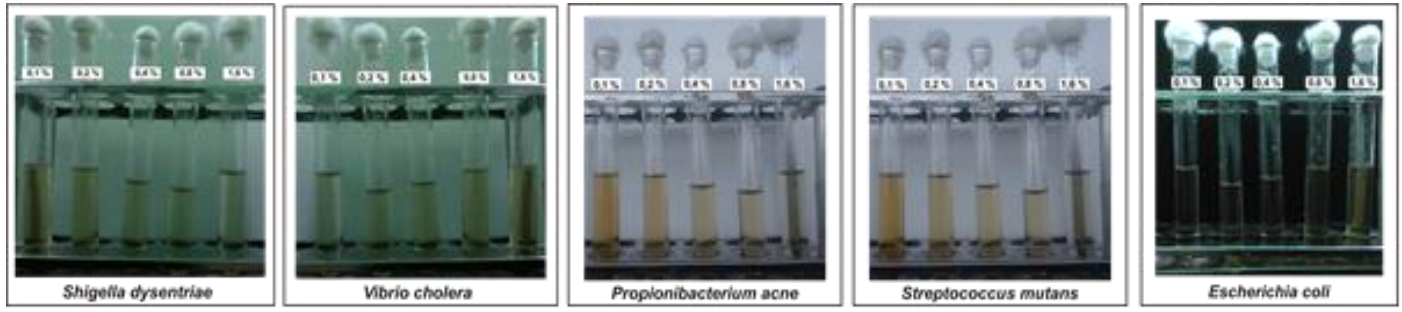

Gambar 3. Hasil Pengujian KHM serbuk biji kakao pada beberapa bakteri uji

Tabel IV. Hasil pengujian KHM serbuk 0,5\%

\begin{tabular}{llccccc}
\hline & \multicolumn{1}{c}{ Bakteri Uji } & \multicolumn{4}{c}{$\begin{array}{c}\text { Konsentrasi Hambat Minimum (KHM) } \\
\text { Norbuk biji kakao (Theobroma cacao) }\end{array}$} \\
\cline { 3 - 6 } & & $\mathbf{0 , 2 5 \%}$ & $\mathbf{0 , 5 \%}$ & $\mathbf{1 \%}$ & $\mathbf{2 \%}$ & $\mathbf{4 \%}$ \\
\hline 1. & Staphylococcus aureus & - & + & + & + & + \\
2. & Salmonella thypi & - & + & + & + & + \\
3. & Pseudomonas aeruginosa & - & + & + & + & + \\
4. & Bacillus subtilis & - & + & + & + & + \\
5. & Staphylococcus Epidermidis & - & + & + & + & + \\
\hline
\end{tabular}
Keterangan:

- $\quad=$ Tidak menghambat

$+\quad=$ Menghambat
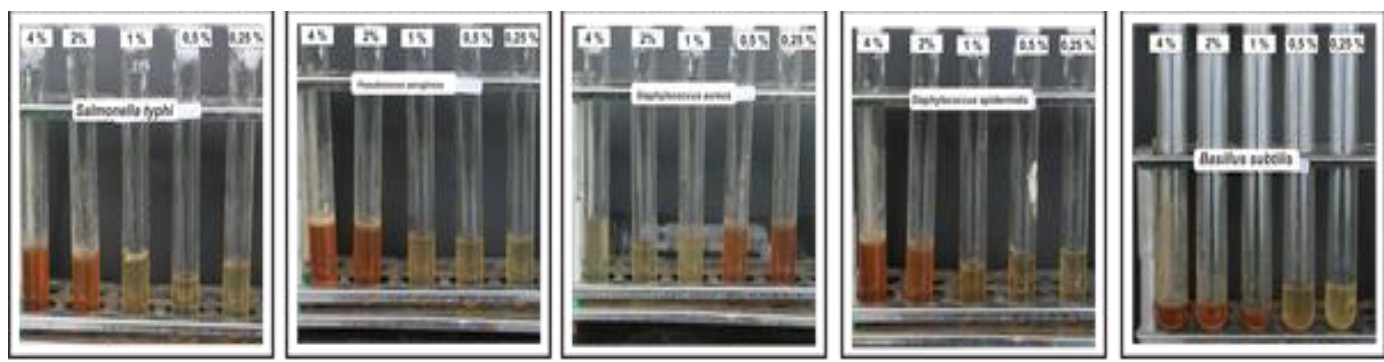

Gambar 4. Hasil pengujian KHM serbuk biji kakao 0,5\% pada beberapa bakteri uji

Pada Tabel III dan Gambar 3 menunjukkan konsentrasi hambat minimum 0,1\% pada bakteri uji Streptococcus mutans, Shigella dysentriae, Vibrio cholera, dan P.Agne dan 0,2\% pada bakteri Escherichia coli.

Pada Tabel IV dan Gambar 4 menunjukkan KHM ekstrak 0,5 \% terhadap bakteri Staphylococcus aureus, Salmonella thypi, Pseudomonas aeruginosa, Bacillus subtilis, Staphylococcus Epidermidis ditunjukkan pada konsentrasi $0,5 \%$. 


\section{Pengujian Konsentrasi Bunuh Minimum (KBM)}

Tabel V. Hasil pengujian KBM serbuk biji kakao 0,1 \%

\begin{tabular}{|c|c|c|c|c|c|c|}
\hline \multirow[t]{2}{*}{ No } & \multirow[t]{2}{*}{ Bakteri Uji } & \multicolumn{5}{|c|}{$\begin{array}{l}\text { Konsentrasi Bunuh Minimum (KBM) } \\
\text { Serbuk biji kakao (Theobroma cacao) } \\
\end{array}$} \\
\hline & & $0,1 \%$ & $0,2 \%$ & $0,4 \%$ & $0,8 \%$ & $1,6 \%$ \\
\hline 1. & Streptococcus mutans & - & - & + & + & + \\
\hline 2. & Shigella dysentriae & - & - & - & + & + \\
\hline 3. & Escherichia coli & - & + & + & + & + \\
\hline 4. & Vibrio cholera & - & + & + & + & + \\
\hline 5. & P.Agne & - & - & + & + & + \\
\hline
\end{tabular}

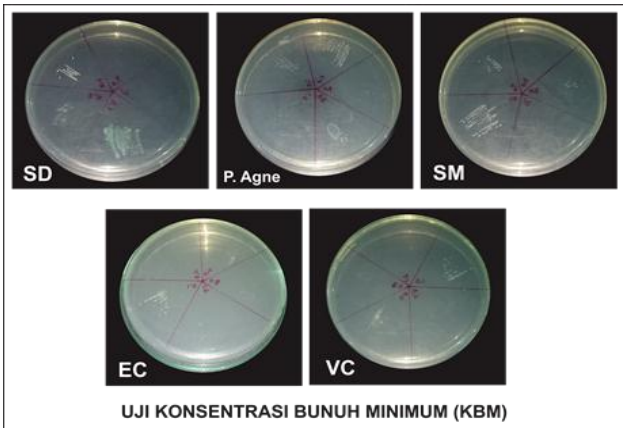

Gambar 5. Hasil pengujian KBM serbuk biji kakao 0,1 \% terhadap beberapa bakteri uji

Pada pengujian KBM terhadap bakteri Streptococcus mutans dan P.Agne ditunjukkan pada konsentrasi 0,4\%, bakteri Escherichia coli, Vibrio cholera ditunjukkan Konsentrasi Bunuh Minimum pada konsentrasi 0,2\% sedangkan Shigella dysentriae pada konsentrasi 0,8\%.

Tabel VI. Hasil pengujian KBM serbuk 0,5 \%

\begin{tabular}{|c|c|c|c|c|c|c|}
\hline \multirow[t]{2}{*}{ No } & \multirow[t]{2}{*}{ Bakteri Uji } & \multicolumn{5}{|c|}{$\begin{array}{c}\text { Konsentrasi Hambat Minimum (KHM) } \\
\text { Serbuk biji kakao (Theobroma cacao) }\end{array}$} \\
\hline & & $0,25 \%$ & $0,5 \%$ & $1 \%$ & $2 \%$ & $4 \%$ \\
\hline 1. & Staphylococcus aureus & - & - & + & + & + \\
\hline 2. & Salmonella thypi & - & - & + & + & + \\
\hline 3. & Pseudomonas aeruginosa & - & - & + & + & + \\
\hline 4. & Bacillus subtilis & - & - & + & + & + \\
\hline 5. & Staphylococcus Epidermidis & - & - & + & + & + \\
\hline \multicolumn{7}{|c|}{ Keterangan: } \\
\hline $\begin{array}{l}- \\
+\end{array}$ & $\begin{array}{l}=\text { Tidak menghambat } \\
=\text { Menghambat }\end{array}$ & & & & & \\
\hline
\end{tabular}

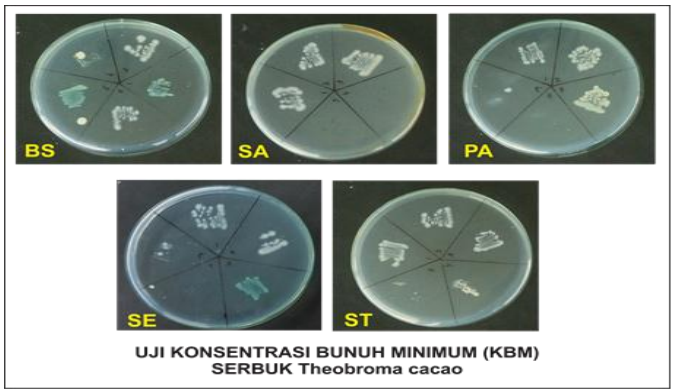

Gambar 6. Hasil pengujian KBM serbuk biji kakao 0,1 \% terhadap beberapa bakteri uji

Pada pengujian KBM terhadap bakteri Staphylococcus aureus, Salmonella thypi, Pseudomonas aeruginosa, Bacillus subtilis, Staphylococcus Epidermidis ditunjukkan pada konsentrasi $1 \%$. 
Tabel VII. Uji aktivitas antimikroba serbuk biji kakao terhadap beberapa bakteri uji

\begin{tabular}{lcccc}
\hline \multirow{2}{*}{\multicolumn{1}{c}{ Bakteri Uji }} & \multicolumn{5}{c}{ Rata-rata Diameter Zona Hambatan } \\
& $\mathbf{0 . 5}$ & $\mathbf{1 \%}$ & $\mathbf{2 \%}$ & $\mathbf{4 \%}$ \\
\cline { 2 - 5 } & $\mathbf{\%}$ & & & \\
\hline Vibrio cholera & 7 & 8 & 10 & 11,33 \\
Shigella dysentriae & 7 & 8 & 8 & 10 \\
Streptococcus mutans & 7 & 8 & 9 & 10 \\
Escherichia coli & 7 & 8 & 9 & 10 \\
Propioni bacterium acne & 7 & 8 & 8 & 10 \\
Salmonella thypi & 7 & 8 & 10 & 11 \\
Staphylococcus Epidermidis & 7 & 8 & 10 & 11 \\
Staphylococcus aureus & 7 & 8 & 9 & 10 \\
Bacillus subtilis & 7 & 8 & 9 & 10 \\
Pseudomonas aeruginosa & 7 & 8 & 10 & 12 \\
\hline
\end{tabular}

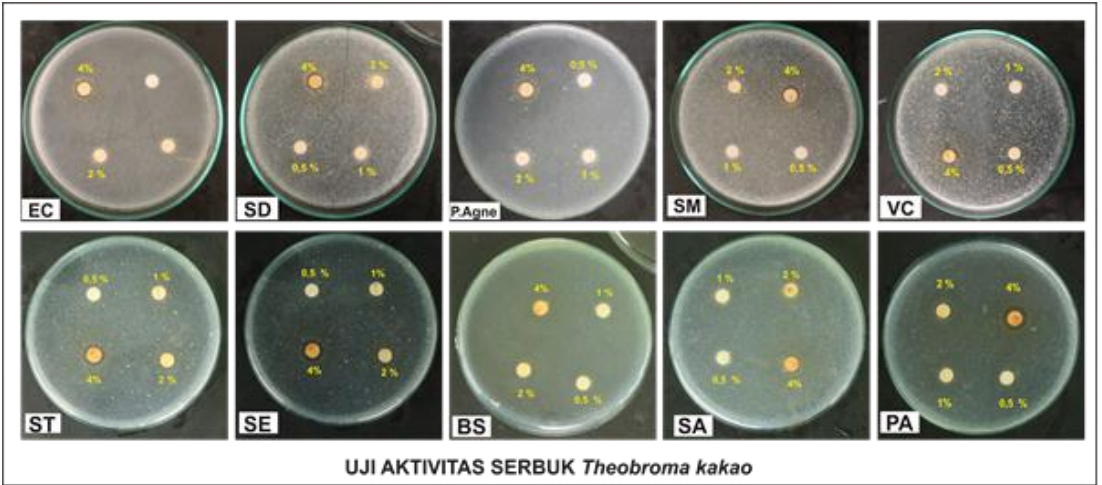

\section{Gambar 7. Uji Aktivitas antimikroba serbuk biji kakao terhadap beberapa bakteri uji}

Tabel VII dan Gambar 7 memperlihatkan aktivitas antimikroba menggunakan konsentrasi 0,5\%, $1 \%, 2 \%$ dan $4 \%$. Zona hambatan terbesar ditunjukkan pada konsentrasi 4\%. Diameter zona hambat untuk bakteri Shigella dysentriae adalah 11,33 mm. Diameter zona hambat $10 \mathrm{~mm}$ ditunjukkan oleh bakteri Streptococcus mutans, Escherichia coli, Propioni bacterium agne, Staphylococcus aureus dan Bacillus subtilis. Zona hambat $11 \mathrm{~mm}$ ditunjukkan oleh Salmonella thypi dan Staphylococcus Epidermidis, sedangkan Pseudomonas aeruginosa menunjukkan zona hambatan $12 \mathrm{~mm}$.

\section{KESIMPULAN}

Serbuk biji kakao yang dibuat dalam kondisi unfermented memberikan total flavanoid yang tinggi serta memiliki Aktivitas antimikroba yang lebih baik pada konsentrasi 0,5\% dibandingkan 0,1\%.

\section{UCAPAN TERIMAKASIH}

Ucapan terimah kasih kepada Kemenristek Dikti yang telah mendanai penelitian ini dan semua pihak yang telah membantu dalam penyelesaian penelitian ini.

\section{DAFTAR PUSTAKA}

Cheynier, V, 2012, Phenolic Compounds: from plants to foods, Phytochemistry Reviews, 11, 152-177.

Dai, J. and Mumper, P. J., 2010, Plant Phenolics: Extraction, Analysis and Their Antioxidant and Anticancer Properties, Molecules, 15: 7313-7352.

Efendi, Y.N and Hertiani,T., 2013, Potensi antimikroba ekstrak etanol sarang semut (Myrmecodia tuberosa Jack.) terhadap Candida albicans, Escherichia coli dan Staphylococcus aureus, Trad.Med. J., 18(1): 53-58 ISSN: 1410-5918.

Emelda, A. and Wahyudin, E., 2014, High levels of flavonoids and HPLC profile from purified extract of cocoa bean from West Sulawesi Indonesia, International Journal of ChemTechResearch, 6(4): 2363-2367. 
Emelda, A., Rusli and Nurlina., 2015, Polyphenol content in powder and purified extract of unfermented cocoa beans from Enrekang regency of South Sulawesi Indonesia, Journal of Chemical and Pharmaceutical Research, 7(9):972-974.

Kurniawan B, Aryana w,F.,2015 Binahong (Cassia alata 1) as inhibitor of Escherichiacoli, J. Majority, 4: nomor 4,|100

Latif, R., 2013, Health benefits of cocoa. Current Opinion in Clinical Nutrition and Metabolic Care, 16: 669-674.

Lucena, A.P.S., Nascimento, R.J.B., Maciel, J.A.C. \& Tavares, J.X., 2010, Antioxidant activity and phenolic content of selected brazilian wines, Journal of Food Composition and Analysis, 23: 3036.

Maleyki, A. and Ismail, A., 2010, Antioxidant properties of cocoa powder, Journal of Food Biochemistry, 34: 111-128.

Marinova,D.,Ribarova,F., Atanassova,M., 2005, Total phenolics and total flavanoids in bulgarian fruits and vegetables. Partement of Food Chemistr National Center of Public Health Protection, Departement of Food Chemistry, Sofia 1431, Bulgaria, 40(3):255-260.

Miller, K.B., Hurst, W.Y., Flannigan N., Ou B., Lee, C.Y., Smith, N., Stuart, D. A,, 2009, Survey of Commercially Available Chocolate- and Cocoa-Containing Products in the

Miranti, M., Prasetyorini dan Suwary, C.,2013, Perbandingan aktivitas antibakteri ekstrak etanol 30\% dan 96\% kelopak bunga rosella (Hibiscus Sabdariffal) terhadap bakteri Staphylococcus aureus, Ekologia, 13(1): 9-18

Ouattara, D.H., Ouattara, H.G., Goualie, B.G., Kouame, L.M., and Niamke, S.L., 2014, Biochemical and functional properties of lactic acid bacteria isolated from ivorian cocoa fermenting beans, Journal of Applied Biosciences, 77: 6489-6499. 